\title{
Improving Students Speaking Ability Through Storytelling at Eleventh Grade of SMAN I Lambitu
}

\author{
Ika Irawati, Fitri Ningsi*, Rahmi, Ita Fitriati \\ STKIP Taman Siswa Bima, Bima, Indonesia \\ *Coresponding Author: ningsifitri899@gmail.com
}

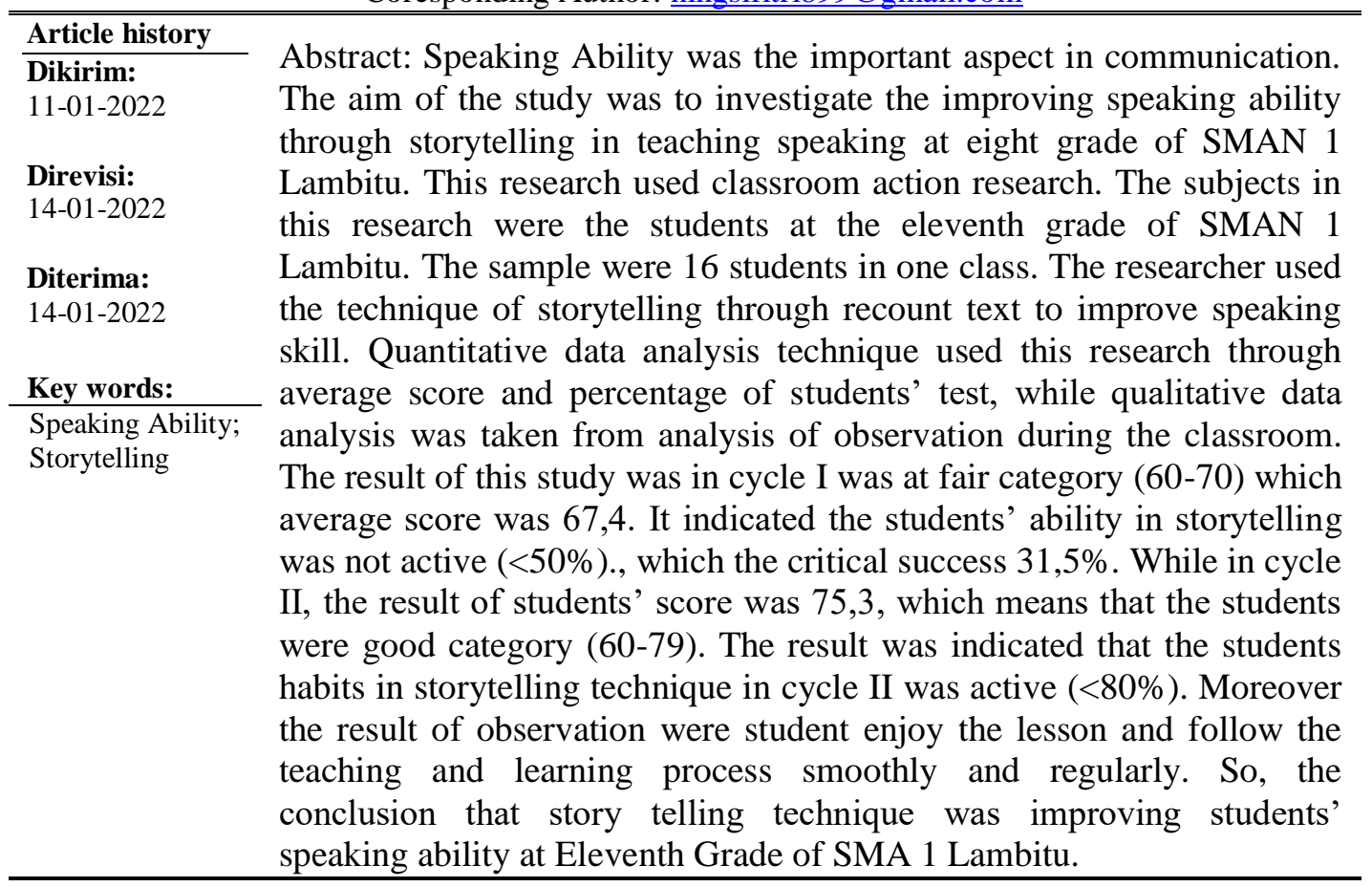

\section{INTRODUCTION}

Speaking is part of the language skills which is important for language learners to be developed. Furthermore, According to Richards (2008) as foreign language learners, we should master speaking skill in English as our priority. So speaking skill have uniqueness on the speakers. The Indonesian government explicitly emphasizes that the aim of teaching and learning of English in Indonesia is to make the students do something good with English. According to Thornburry (Inayah 2005) speaking is a part of daily life that we take it for granted. Brown (2001) defines speaking as the process of interactive of constructing meaning, receiving and processing the information. Communication could be run well through speaking, so the speaker and listener can share the information and experiences clearly. Related to the process of interaction, they who are involved in interaction will get valuable feedback from each other.

The aim in the speaking skill is challenging, so it is not easy thing. The teachers and students many problems in the teaching and learning of speaking. The inconvenient condition was appeared by the monotonous teaching technique used by some teachers. Also sometimes the classroom activities tended to be teacher centered. Some students sometimes were only passive in the teaching and learning process. Moreover, students who are busy talking to themselves, eating in class, and 
others. This is evidenced by the compilation of the teacher teaching. Achievement value at SMAN 1 Lambitu is also not implemented well, this can be seen from the still lack speaking students.

The research find the problems related into speaking the lack speaking ability student's. Speaking students was not improved at class XI IN SMAN I Lambitu. Many of them are not talk using English. The teacher invited them to speak with English. Many of them could not understand what was mentioned. This in ability denied because they cannot communicate in English, method that encourage inadequate teachers and their environment is not supportive. Based on interviews conducted with this eye- catching teachers, information was obtained about the average grades of English students in class XI not yet reaching the minimum standard. Therefore from the problems above in SMAN I Lambitu speaking students Eleventh Grade in SMAN I Lambitu through storytelling.

\section{LITERATURE REVIEW}

\section{Speaking Ability}

The ability to speak is shared by all humans. But speaking skill in front of people is not necessarily possessed by everyone. The speaker must develop techniques for preparation, for structuring the conversation, for transmitting energy and enthusiasm, and responding to the listeners interests. The basic of an effective conversation is competent preparation. In this day and age all people are required to be skill in speaking. Brown (2001) defines speaking as an interactive. Process of constructing meaning, involving producing, receiving, and processing information. Its form and meaning are dependent on the context in which it occurs, including the participant, their collective experiences, the physical environment, and the purpose of speaking. Related to the process of interaction, they who are involved in interaction will get valuable feedback from each other. Harmer (2001) explains, in many situations productive skill is combined with the practice of receptive skills. The conversation between two or more people is a blend of listening and speaking where the comprehension of what has been said is necessary for what the participant says next. The two kinds of language skills: receptive and productive skills should be taught to the students in language instruction. Receptive skills are the ways in which people extract meaning from the discourse they see or hear.

Brown (2004:141) there are three basic types' on speaking, namely; imitative, intensive and responsive. Which these types always connect each other and build the languages well in communication.

\section{Storytelling}

Coconi (2013) defined Storytelling is the communicating of events through the use of words and sounds. This is an art of expression and improvisation, which revolves around a plot and/or narrative point of view. There are a number of different types of storytelling that are shared within many different cultures of the world, aiming to spread moral values, entertainment, inspiration and advice. According to Safdarian (2013: 208) defines storytelling as the way of the students to retell stories in own languages after being told the stories by their teacher in the class. So the students could retell to the teacher and friends clearly. Then, Ebrahiminejad et al., (2014: 43) say that storytelling is one eaching technique by using short stories. According to Ling in Julia (2015: 14), storytelling as a learner-centered method helps 
the students to use and share their stories and experiences to others. So the students learning with Fun and enjoy situation.

Based on the statement above that storytelling can provide fun, excitement, prosperity, develop imagination, provides new experiences, develop children's insights and decrease the cultural heritage of the next generation of generations. The most important thing, that storytelling can enrich the insights that children have to develop and become human behavior, which considers the good and bad actions taken Storytelling is a higher art of storytelling and requires a lot of practice as one of the art of storytelling. Storytelling is a useful activity in learning. Storytelling can foster motivation to listen to stories or tell stories.

\section{METHOD}

This type of research was classroom action research, participant action. Means that a person who took action that must be done in the research process from the beginning. This class action research used a model of action research which type of research was classroom action research conducted collaboratively. In collaborative research, the researcher acted as a teacher. While the teacher as the observer in the teaching and learning process. The steps of the research were Cycle I consist of planning, action, observation, and reflection. Than the researcher conduct the Cycle II, when the average score and percentage were not active $(<50 \%)$.

\section{RESULT AND DISCUSSION}

\section{A. Description of Previous Ability}

The students' speaking ability were poor, where the students were passive in the classroom. The teacher was the center of the learning. Many of them could not understand what was mentioned. This in ability denied because they cannot communicate in English, method that encourage inadequate teachers and their environment is not supportive. Based on interviews conducted with this eyecatching teachers, information was obtained about the students' average score of English subject in class XI were poor, moreover the percentages of speaking ability was low.

\section{B. Description Result of Cycle I}

\section{Planning Action}

The activity was done on Tuesday august $17^{\text {Th }}$ and to Friday august $21^{\text {Th }}$ 2020. Here the researcher as teacher taught the students of XI- MIA 1 to a clear important English speaking ability which can be facilitated through story telling. The Researcher prepared the lesson plan, material, and supporting media.

2. Action

In this phase the researcher describe the activities were done in the class briefly with paying attention to the process of learning by using storytelling. The activities were as follow:

a) In the initial activity, the researcher started the class by praying with the students led by the class chief was Ramadan afterward, the researcher as teacher told the students the learning objective. Students to pay attention to the teacher while teacher present. And then explain the material about storytelling. 
b) The research as teacher asked the student attention and the researcher gave the instruction to the students then gave them their storytelling.

c) The researchers give material about the storytelling and what is storytelling, how become story teller is better. Gave to student text about the story telling. And then explain what do students with text. The teacher give the chance students for choose the topic is free about the story telling in order to development speak students

d) Teacher gives the chance to students for the performance storytelling unforgettable experiences.

e) The researcher gave instruction students for text memorized.

f) After all of the students did their job, the teacher give feedback on students' performance.

3. Observation

The teaching and learning process were done. The result of observation; the students were motivated in study, but they were not prepared yet in speaking. Many students laugh when error pronunciation.

4. Reflection

The teacher was reflecting and evaluating the learning activities in the first cycle and tried to get solution on the problem by planning some action such as below:

Teacher asked to students to focus on study and not make noises. teacher should motivate students to be more active. The students less of confidence, and could not develop the language. Many of them silent, when they forgot. Teacher noted all active in class in learning process. The result from reflecting used to make improvement. It was also used reflecting for doing second cycle to get maximum experiences.

\section{Description Result of Cycle II}

1. Planning Action

In this cycle the teacher used the same strategy as the previous meeting and the teaching learning process ran well. The second cycle was about how teaching and learning process through storytelling was fixed refers to the weakness found. The process was followed by 16 students of class XI MIA I.

2. Action

In this phase the researcher describe the activities were done in the class briefly with paying attention to the process of learning by using storytelling. The first teaching opening the class by recited Pray together, then teacher explains the simple steps to tell story. Than the teacher give example of storytelling through recount text. The teacher gave opportunity to student to tell the story. It could the students' experiences in their lifes.

3. Observation

The teaching and learning process were done. The english teacher acted as observer in the class. The result of observation; the students were motivated in study. The students got confidence to tell their recount text using storytelling. They could develop their speaking ability through the story.

4. Reflection

Reflection result in cycle II, some problems which occurred in cycle I can be minimized, teaching and learning process run well. Students got more 
motivation and confidence to tell the story though storytelling technique. Students could develop their languages. Moreover, classroom condition was active. When the researcher did the cycle I, some of students are good when used storytelling technique. But some of students still less in speaking. The researcher made note and reflection related to students' weaknesses.

In cycle II, the researcher gave illustration and assessment to students who less in speaking and confidence. Taught students step by step to develop their languages through storytelling technique. So the students could follow the steps and get confidence to start their recount based on their real experiences.

\section{Result of Action}

Based on the teaching and learning process started from cycle I until cycle II, there were the improvements of students condition, they got motivation and confidence. Moreover they could increase the ability in speaking through storytelling technique. The brief description could be seen in the following Table.

Table 1. Students' Improvement from cycle II to cycle II

\begin{tabular}{cllll}
\hline No & $\begin{array}{l}\text { Previous } \\
\text { condition }\end{array}$ & \multicolumn{1}{c}{ Cycle I } & \multicolumn{1}{c}{ Cycle II } & $\begin{array}{c}\text { Reflection of previous to } \\
\text { end }\end{array}$ \\
\hline & $\begin{array}{l}\text { Students } \\
\text { were lack of } \\
\text { motivation } \\
\text { and } \\
\text { confidence }\end{array}$ & $\begin{array}{l}\text { Student get } \\
\text { little } \\
\text { motivation and } \\
\text { confidence }\end{array}$ & $\begin{array}{l}\text { Student get } \\
\text { much } \\
\text { motivation } \\
\text { and } \\
\text { confidence }\end{array}$ & $\begin{array}{l}\text { There were improvement } \\
\text { from the previous condition } \\
\text { in motivation and } \\
\text { confidence }\end{array}$ \\
\hline & $\begin{array}{l}\text { Students } \\
\text { were lack of } \\
\text { speaking }\end{array}$ & $\begin{array}{l}\text { Students start } \\
\text { to speaking, } \\
\text { but made much } \\
\text { mistake }\end{array}$ & $\begin{array}{l}\text { Students } \\
\text { were better } \\
\text { in speaking } \\
\text { through } \\
\text { storytelling } \\
\text { technique }\end{array}$ & $\begin{array}{l}\text { There were improvements } \\
\text { from the previous condition } \\
\text { in speaking ability. They } \\
\text { could used storytelling. }\end{array}$ \\
\hline & $\begin{array}{l}\text { Students } \\
\text { were passive }\end{array}$ & $\begin{array}{l}\text { Students got a } \\
\text { little bit active }\end{array}$ & $\begin{array}{l}\text { Students } \\
\text { more active }\end{array}$ & $\begin{array}{l}\text { There were improvements } \\
\text { from the previous condition } \\
\text { from passive to active. }\end{array}$ \\
\hline
\end{tabular}

The results of observation form the teacher as the observer that students were active to participate in the class. The class runs regularly and smoothly.

Table 2. Students' Improvement in Speaking Ability from cycle II to cycle II

\begin{tabular}{|c|c|c|c|c|}
\hline No & $\begin{array}{l}\text { Previous } \\
\text { condition }\end{array}$ & Cycle I & Cycle II & $\begin{array}{l}\text { Reflection of } \\
\text { previous to end }\end{array}$ \\
\hline 1 & $\begin{array}{l}\text { The students were } \\
\text { low ability in } \\
\text { speaking, less } \\
\text { motivation. } \\
\text { Students score } 50 \\
\text { Maximum score } \\
55\end{array}$ & $\begin{array}{l}\text { Students' } \\
\text { score in cycle } \\
\text { I was at fair } \\
\text { category ( } 60- \\
70 \text { ) which } \\
\text { average score } \\
\text { was } 67,4\end{array}$ & $\begin{array}{l}\text { While in cycle II, } \\
\text { the result of } \\
\text { students' score } \\
\text { was } 75,3 \text {, It } \\
\text { means that the } \\
\text { students were } \\
\text { good category } \\
(60-79) .\end{array}$ & $\begin{array}{l}\text { From the previous } \\
\text { condition until the } \\
\text { last, there was } \\
\text { improvement of } \\
\text { students' score in } \\
\text { speaking ability } \\
\text { from } 67,4 \text { to } 75,3 \text {. }\end{array}$ \\
\hline
\end{tabular}




\section{CONCLUSION}

Most of students said that speaking ability was difficult skill to master. But when the researcher elaborated with the students, and introduced the storytelling technique to express their language through the story. Students more enjoy and got motivation to study. The result of the study that Students were better in speaking through storytelling technique, in cycle II, the result of students' score was 75,3, It means that the students were good category (60-79). So it concluded that there was improvement of students' score in speaking ability from 67,4 to 75,3 .

The students cycle II was active $(<80 \%)$. The result of observation were student enjoy the lesson and follow the teaching and learning process smoothly and regularly. So, the conclusion that storytelling technique could improve students' speaking ability at Eleventh Grade of SMA 1 Lambitu.

\section{REFERENCES}

Brown, H.D. (2001). Teaching by Principles: An Interactive Approach to Language Pedagogy. New York: Addison Wesley Longmn Inc.

Coconi,A. (2013). [Online] Available http://www.ehow.com/info_8771474_types storytelling.html [June 11 2014]

Ebrahiminejad, S., Azizifar, A., Gowhary, H., \& Jamalinesari, A. (2014). Effect of using short story on speaking improvement of Iranian pre-intermediate EFL learners. International Journal of Language Learning and Applied Linguistics World (IJLLALW), 7(3), 42-5

Harmer, J. (2001). How to Teach English: An introduction to the practice of English Language Teaching.Kualalumpur: Longman.

Julia, H. T. (2015). Telling tales: Using storytelling to teach EFL kindergarten students in Taiwan. International Journal of Research Studies in Education, 4(4), 13-25. doi: 10.5861/ijrse.2015.848

Richard, J.C. (2008). Teaching Listening and Speaking: From Theory to Practice. New York: Cambridge University Pres

Safdarian, Z. (2013). The effect of stories on young learners' proficiency and motivation in foreign language learning. International Journal of English and Education, 2(3), 200-248. 